\title{
Les Carnets de l'ACoSt
}

Association for Coroplastic Studies

19 | 2019

Varia

\section{A Wayside Shrine in Northern Moab. Excavations in the Wadi Ath-Thamad}

P. M. Michele Daviau and Margreet L. Steiner

\section{(2) OpenEdition}

\section{Journals}

Electronic version

URL: http://journals.openedition.org/acost/2036

DOI: $10.4000 /$ acost.2036

ISSN: 2437-8574

Publisher

ACoSt

\section{Electronic reference}

P. M. Michele Daviau and Margreet L. Steiner, «A Wayside Shrine in Northern Moab. Excavations in the Wadi Ath-Thamad », Les Carnets de l'ACoSt [Online], 19 | 2019, Online since 11 June 2019, connection on 23 September 2020. URL : http://journals.openedition.org/acost/2036 ; DOI : https://doi.org/10.4000/ acost.2036

This text was automatically generated on 23 September 2020.

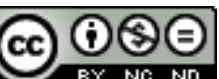

Les Carnets de l'ACoSt est mis à disposition selon les termes de la licence Creative Commons Attribution - Pas d'Utilisation Commerciale - Pas de Modification 4.0 International. 


\section{A Wayside Shrine in Northern Moab. Excavations in the Wadi Ath-Thamad}

P. M. Michele Daviau and Margreet L. Steiner

\section{REFERENCES}

P. M. Michele Daviau, Margreet L. Steiner (eds), A Wayside Shrine in Northern Moab. Excavations in the Wadi Ath-Thamad, Oxbow Books, 2017. 
1 Major recent excavations have shed much light on the complexity of Iron Age society and religion in southern Palestine, a region where both Judeans and Edomites lived. However, it is not clear whether the religious practices attested at these sites were a reflection of localised customs or were common rituals for peoples of Cisjordan and we do not know their extent. An isolated shrine site at Wadi ath-Thamad Site WT-13 in northern Moab which contained numerous finds of Iron Age figurines and statues has been the subject of detailed excavation. The rich harvest of figurines, ceramic statues, beads, miniature ceramic vessels, architectural models, faunal remains and

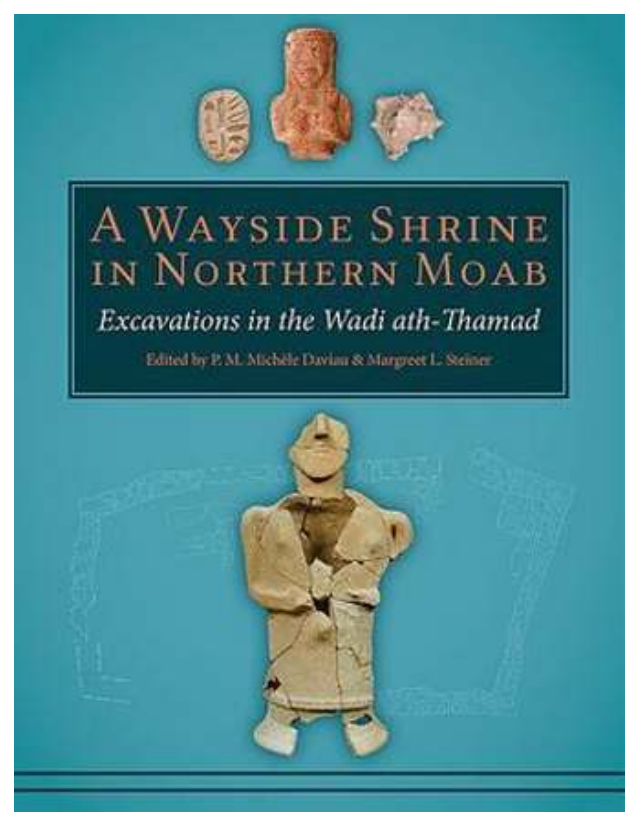
shells and fossils constitutes the evidence for repeated cultic activities. Although dating to the Iron Age at the time of the consolidation of the kingdom of Moab, there is insufficient evidence at present to determine the full range of cultic practices and deities venerated by the peoples of the lands within ancient Moab and by those visitors to the shrine. The links between WT-13 and the surrounding town sites is only now coming to light with excavation at Atarus and Khirbat al-Mudayna, as well as at the Ammonite site of Tall Damiyah in the Jordan Valley, where a comparable shrine has recently been uncovered. WT-13 clearly serves as a link between the Jordan Valley and the Negev, adding to our knowledge of local and foreign influences in the region during the Iron Age.

\section{ABSTRACTS}

An isolated Iron-Age shrine at Wadi ath-Thamad Site WT-13 in northern Moab contained numerous finds of figurines and statues that contribute to our understanding of repeated cultic activities at the site.

\section{INDEX}

Keywords: Northern Moab, Atarus, Khirbat al-Mudayna, Tall Damiyah, Cisjordan rituals. 